\title{
ANALISIS FAKTOR YANG MEMPENGARUHI PENDAPATAN PELAKU UKM SEKTOR PERDAGANGAN KIOS DI KECAMATAN ENDE UTARA
}

\author{
Lambertus Langga \\ Program Studi Manajemen, Fakultas Ekonomi, Universitas Flores \\ e-mail: langggalambertus@yahoo.com
}

\begin{abstract}
Abstrak
Pelaku UKM merupakan suatu usaha yang berada di Kecamatan Ende Utara, sampel penelitian pada pelaku usaha kecil dan menengah khusus pada usaha kios . studi ini bertujuhan untuk mengkaji faktor yang mempengaruhi pendapatan pelaku usaha sektor perdagangan kios, dan data-data dikumpulkan melalui wawancara, FGD dan dilakukan dengan menggunakan analisis regresi linier. Adapun variabel dalam penelitian ini adalah: (1)Modal terhadap pendapatan perdagangan kios di Kecamatan Ende Utara; (2) Volume Penjualan terhadap pendapatan perdagangan kios di Kecamatan Ende Utara; (3) Jam Kerja terhadap perdagangan kios di Kecamatan Ende Utara; (4) Lokasi terhadap pendapatan perdagangan kios di Kecamatan Ende Utara. Penelitian ini termasuk penelitian kausalitas dengan menggunakan pedekatan kuantitatif. Sampel dalam penelitian ini konsumen yang memiliki usaha kios di Kecamatan Ende Utara berjumlah 80 orang. Hasil penelitian ini menunjukan bahwa:(1) Modal memiliki pengruh positif dan signifikan terhadap pendapatan perdagangan kios di Kecamatan Ende Utara. dengan nilai $(\beta)$ sebesar 0,278; (2) Volume Penjualan memiliki pengruh positif dan signifikan terhadap pendapatan perdagangan kios di Kecamatan Ende Utara. dengan nilai ( $\beta$ )sebesar 0,262; (3) Jam Kerja memiliki pengruh positif dan signifikan terhadap pendapatan perdagangan kios di Kecamatan Ende Utara. dengan nilai $(\beta)$ sebesar 0,191; (4) Lokasi memiliki pengruh positif dan signifikan terhadap pendapatan perdagangan kios di Kecamatan Ende Utara. dengan nilai $(\beta)$ sebesar 0,214 .
\end{abstract}

Kata Kunci : modal, volume penjualan, jam kerja, lokasi dan pendapatan.

\begin{abstract}
The SME actor is a business located in North Ende District, the research sample is on small and medium enterprises specifically in the kiosk business. This study aims to examine the factors that influence the income of the kiosk trading sector business actors, and the data were collected through interviews, FGDs, and carried out using linear regression analysis. The variables in this study are: (1) Capital to income from kiosk trading in North Ende District; (2) Sales volume against kiosk trade income in North Ende District; (3) Working hours of kiosk trade in North Ende District; (4) Location of kiosk trade income in North Ende District. This research includes causality research using a quantitative approach. The sample in this study is that consumers who have kiosk businesses in North Ende District are 80 people. The results of this research indicate that: (1) Capital has a positive and significant impact on kiosk trade income in North Ende District. with a value ( $\beta$ ) of 0.278; (2) Sales volume has a positive and significant impact on kiosk trading income in Ende Utara District. with a value ( $\beta$ ) of 0.262: (3) Hours of work have a positive and significant impact on kiosk trade income in North Ende District. with a value $(\beta)$ of 0.191 ; (4) Location has a positive and significant impact on kiosk trading income in Ende Utara District. with a value ( $\beta$ ) of 0.214.
\end{abstract}

Keywords: capital, sales volume, working hours, location and income. 


\section{PENDAHULUAN}

Keadaan ekonomi dalam suatu masyarakat sangat ditentukan oleh tinggi rendahnya pendapatan. Pendapatan sering dijadikan tolak ukur dalam mengukur suatu tingkat kesejahteraan masyarakat dan keberhasilan pembangunan ekonomi suatu Negara. Kuatnya daya tahan usaha kecil dan menengah karena didukung oleh konsistensi mereka dalam memproduksi barang maupun jasa yang mereka perdagangkan dan kemampuan mereka dalam menciptakan lapangan pekerjaan dan memberi upah pada karyawannya. Potensi UKM ini dipandang sebagai senjata untuk mendongkrak pertumbuhan ekonomi masyarakat. Selain membawa dampak langsung, UKM juga dipandang sebagai salah satu upaya pembangunan ekonomi daerah yang berkelanjutan dan ramah lingkungan jika dibandingkan dengan sektor ekstratif, seperti pertambangan skala besar. Usaha kecil menengah terbukti mampu menampung 94,45 persen dari total tengan kerja atau 73,24 juta tenga kerja.(Maheswara, Setiawarna, \& Saskara, 2016)

Tahun demi tahun sektor UKM terus mengalami peningkatan karena didukung oleh konsistensi mereka dalam memproduksi barang maupun jasa yang mereka perdangan dan kemampuan mereka dalam menciptakan lapangan pekerjaan dan memberi upah pada karyawannya. Berdasarkan data BPS Kabupaten Ende, total UKM yang beroperasi di Kota Ende berjumlah 744 UKM. Kecamatan Ende Utara memiliki jumlah toko 11 toko dan 404 kios. Wilayah Kecamatan Ende Utara merupakan wilayah di Kota Ende yang memiliki pertumbuhan UKM yang sangat tinggi dengan total 404 pelaku UKM yang sesuai dengan data dari BPS Kabupaten Ende.

Jika dilihat dari hasil uraian pada latar belakang diatas sesuai dengan data yang peneliti survei dari Badan Pusat Statistik Kabupaten Ende tentang data pelaku UKM tahun 2018, menunjukkan tingkat pertumbuhan pelaku UKM di empat Kecamatan dengan selisih pertumbuhan yang cukup jauh berbeda. Dari sisi pendapatan perdagangan dapat dikatakan bahwa sudah tidak menguntungkan, namun dengan banyaknya pelaku UKM yang baru maka akan sangat berdampak pada pendapatan atau omset para pelaku UKM. Tujuan dari penelitian ini adalah untuk mengetahui faktor modal , volume penjualan, jam kerja, lokasi berpengaruh terhadap pendapatan para pelaku UKM sektor perdagangan kios di Kecamatan Ende Utara Kabupaten Ende. 


\section{TINJAUAN PUSTAKA}

\section{a) Usaha Kecil Menengah (UKM)}

Usaha kecil merupakan usaha ekonomi produksi yang berdiri sendiri, yang dilakukan oleh perorangan atau badan usaha yang bukan merupakan anak perusahaan atau bukan cabanag perusahaan yang dimiliki, dikuasai, atau menjadi bagian baik langsung maupun tidak langsung dari usaha menengah atau usaha besar yang memenuhi kriteria usaha kecil sedangkan usaha menengah merupakan usaha ekonomi produktif yang berdiri sendiri, yang dilakukan oleh orang perorangan atau badan usaha yang bukan merupakan anak perusahaan yang dimiliki, dikuasai, atau menjadi bagian baik langsung maupun tidak langsung dengan usaha kecil atau usaha besar (Ernawati, Asyikin, \& Sari, 2016). Menurut Beselly, Mawardi, and Mawardi (2017), usaha kecil menengah merupakan usaha ekonomi produktif miliki orang perorang yang berupa usaha mikro, kecil, dan menengah yang dilihat dari berbagai aspek, baik dari segi kekayaan yang dimilki pelaku, jumlah tenaga kerja yang dimiliki atau dari segi penjualan/omset pelaku UKM.

\section{b) Modal}

Modal merupakan sejumlah harga (uang atau barang) yang digunakan untuk menjalankan usaha. Modal berupa uangtunao, barang dagangan, bangunan, dan lain-lain (Rosidi \& Suparno, 2018)

\section{c) Volume Penjualan}

Penjualan merupakan ilmu dan seni mempengaruhi pribadi yang dilakukan oleh penjual untuk mengajak orang lain bersedia membeli barang atau jasa yang ditawarkan. Volume penjualan merupakan jumlah barang atau jasa yang terjual dalam proses pertukaran (Pradiani, 2017).

\section{d) Jam Kerja}

Menurut Dewi and Arwiyah (2020), jam kerja merupakan waktu untuk melakukan pekerjaan dapat dilakukan siang hari atau pada malam hari, merencanakan pekerjaan yang akan datang dan merupakan langkah-langkah memperbaiki pengaturan waktu. $\quad$ Monika (2011) jam kerja adalah waktu yang dijadwalkan untuk perangkat peralatan yang dioperasikan atau waktu yang dijadwalkan bagi pekerja. Jam kerja meliputi berbagai hal berikut: 
1. Lamanya seseorang mampu bekerja secara baik

2. Hubungan antara waktu kerja dengan waktu istirahat

3. Jam kerja sehari meliputi pagi, siang, sore dan malam.

e) Lokasi

Menurut Amilia (2019), lokasi merupakan salah satu unsur bauran pemasaran yang memegang peranan penting dalam hak=1 mengalokasikan barang atau jasa dan melancarkan arus barang atau jasa dari produsen ke konsumen. Lokasi yang strategis bertujuan untuk memaksimalkan keuntungan dari lokasi bagi UKM. Penentuan lokasi usaha yang tepat akan menjadikan suatu usaha dapat beroperasi dengan lebih efisien dan dapat mencapai pendapatan yang diharapkan. Lokasi merupakan tempat yang menunjukkan berbagai kegiatan yang dilakukanperusahaan untuk menjadikan produknya dapat diperoleh dan tersedia bagi konsumen (Handoko,2000:187).

\section{f) Pendapatan}

Menurut Ritonga (2018), pendapatan merupakan nilai tambah ekonomis yang diterima seseorang atau pelaku usaha yang menjalankan kegiatan usahanya. Dalam kehidupan seharihari manusia selalu mempunyai kebutuhan akan barang dan jasa. Dalam pemenuhan kebutuhannya antara manusia yang satu dengan manusia yang lainnya tentunya akan saling berbeda kebutuhannya. Perbedaan dalam pemenuhan kebutuhan ini disebabkan adanya tingkat pendapatan dari masing-masing manusia tersebut. Berdasarkan hal tersebut, maka seseorang harus bekerja untuk mendapatkan sejumlah pendapatan guna memenuhi kebutuhan akan barang dan jasa.

\section{g) Hipotesis}

Berdasarkan teori dan penelitian sebelumnya serta kerangka berpikir di atas maka yang menjadi hipotesis dalam penelitian ini adalah:

H1: Modal kerja berpengaruh positif dan signifikan terhadap pendapatan para pelaku UKM sektor perdagangan kios Di Kecamatan Ende Utara di Kabupaten Ende.

H2: Volume penjualan berpengaruh positif dan signifikan terhadap para pelaku UKM sektor perdagangan kios di Kecamatan Ende Utara di Kabupaten Ende. 
H3: Jam kerja berpengaruh positif dan signifikan terhadap pedapatan para pelaku UKM sektor perdagangan kios di Kecamatan Ende Utara di Kabupaten Ende.

H4: Lokasi usaha berpengaruh positif dan signifikan terhadap pedapatan para pelaku UKM sektor perdagangan kios di Kecamatan Ende Utara di Kabupaten Ende.

\section{METODE PENELITIAN}

Penelitian ini dilakukan Kecamatan Ende Utara di kota Ende, pada sektor perdagangan, dimana UKM menjadi bagian dari sektor tersebut menjadi salah satu sektor yang terus menglami peningkatan dari tahun ketahun sehingga sangat mendukung untuk dikembangkannya UKM. Disamping itu Kota Ende adalah ibu kota dari Kabupaten Ende dan menjadi pusat area mengembangkan usaha. Dalam penelitian ini data kuantitatif yang digunakan meliputi modal, volume penjualan, jam kerja, lokasi penjualan yang diperoleh dari BPS. Dalam penelitian ini data diperoleh langsung dari responden yaitu pemilik UKM yang menjadi sampel dalam penelitian ini, serta data yang telah diolah dan diterbitkan instansi terkait seperti BPS Kabupaten Ende.

Populasi yang digunakan dalam penelitian ini adalah Usaha Kecil dan Menengah (UKM) di Kota Ende. Penentuan sampel menggunakan Accidental Sampling. Keuntungan dari Accidental Sampling adalah bahwa sampel yang diperoleh lebih mudah karena menentukan sampel pada saat kita penelitian ke lapangan tetapi tetap mewakili setiap sampel.

Data yang digunakan dalam penelitian ini dikumpulkan dengan menggunakan metode sebagai berikut: 1)Wawancara terstruktur dengan menggunakan kuisioner yaitu proses memperoleh data dengan cara tanya jawab dan tatap muka secara langsung antara peneliti dengan responden. Data yang diperoleh melalui wawancara adalah adalah berapa modal yang disediakan, volume penjualan, lamanya jam kerja,dan dimana lokasi penjualan dan besarnya pendapatan yang dihasilkan oleh UKM. 2) Observasi adalah salah satu pengumpulan data dengan melakukan pengamatan secara langsung pada objek yang diteliti. Dalam penelitian ini adalah pengamatan langsung pada UKM di Kota Ende, dengan informan yang dapatdipercaya (Sugiyono, 2013). Dalam hal ini sebagai informan adalah yang dianggap berkompeten memberikan informasi terkait dengan penelitian. 
Published online in http://ejournal.uniflor.ac.id/index.php/analisis

Analisis data dilakukan dengan menggunakan statistik deskriptif dengan alat bantu analisis SPSS. Analisis data yang digunakan adalah uji validitas, uji reliabilitas, uji hipotesis, uji koefisien determinasi, dan uji regresi linear berganda.

\section{HASIL DAN PEMBAHASAN}

\subsection{Deskripsi Hasil Uji Validitas}

Untuk tingkat validitas dilakukan uji signifikansi dengan membandingkan nilai $\mathrm{r}_{\text {hitung }}$ dengan $\mathrm{r}_{\text {tabel. }}$ Untuk degree of freedom $(\mathrm{df})=\mathrm{n}-\mathrm{k}$ dalam hal ini $\mathrm{N}$ adalah jumlah sampel dan $\mathrm{K}$ adalah jumlah konstruk. Pada kasus ini besarnya df dapat dihitung 80-2 atau df $=78$ dengan alfanya 0,05 didapat $r_{\text {tabel. }}$ 0,2199 jika $r_{\text {hitung }}>r_{\text {tabel }}$ dan nilai $\mathrm{R}$ positif maka butir pernyataan tersebut dinyatakan valid. Berikut adalah hasil uji validitas tentang faktor-faktor yang mempengaruhi pendapatan pelaku UKM kios di Kecamatan Ende Utara.

Tabel 1. Hasil Uji Validitas

\begin{tabular}{|c|c|c|c|}
\hline Variabel & R Hitung & R Tabel & Hasil Uji \\
\hline X1.1 & 0,473 & 0,2199 & Valid \\
\hline X1.2 & 0,706 & 0,2199 & Valid \\
\hline X1.3 & 0,406 & 0,2199 & Valid \\
\hline X1.4 & 0,609 & 0,2199 & Valid \\
\hline X2.1 & 0,770 & 0,2199 & Valid \\
\hline X2.2 & 0,662 & 0,2199 & Valid \\
\hline X2.3 & 0,617 & 0,2199 & Valid \\
\hline X2.4 & 0,658 & 0,2199 & Valid \\
\hline X3.1 & 0,693 & 0,2199 & Valid \\
\hline X3.2 & 0,638 & 0,2199 & Valid \\
\hline X3.3 & 0,776 & 0,2199 & Valid \\
\hline X3.4 & 0,510 & 0,2199 & Valid \\
\hline X4.1 & 0,761 & 0,2199 & Valid \\
\hline X4.2 & 0,742 & 0,2199 & Valid \\
\hline X4.3 & 0,770 & 0,2199 & Valid \\
\hline X4.4 & 0,735 & 0,2199 & Valid \\
\hline & & & \\
\hline & & & \\
\hline & & & \\
\hline
\end{tabular}




\begin{tabular}{|c|c|c|c|}
\hline Y1 & 0,773 & 0,2199 & Valid \\
\hline Y2 & 0,735 & 0,2199 & Valid \\
\hline Y3 & 0,697 & 0,2199 & Valid \\
\hline
\end{tabular}

Berdasarkan hasil uraian diatas, dapat dilihat bahwa semua variabel dalam penelitian ini dinyatakan sah atau valid berdasarkan hasil uji validitas diatas dengan $(>0,2199)$ berutur-turut dari variabel X1, X2,X3,X4, Y

\subsection{Deskripsi Hasil Uji Reliabilitas}

Berikut adalah hasil uji reliabilitas yang telah diolah dengan menggunakan program SPSS sistem pengujian statistik yang digunakan pada penelitian ini:

Tabel 2. Hasil Uji Reliabilitas

\begin{tabular}{|c|c|c|c|c|}
\hline Item Variabel & N of Item & R kritis & Cronbach's Alpha & Hasil Uji \\
\hline Variabel X1 & 4 & 0,600 & 0,890 & Reliabel \\
\hline Variabel X2 & 4 & 0,600 & 0,807 & Reliabel \\
\hline Variabel X3 & 4 & 0,600 & 0,862 & Reliabel \\
\hline Variabel X4 & 4 & 0,600 & 0,741 & Reliabel \\
\hline Variabel Y & 3 & 0,600 & 0,865 & Reliabel \\
\hline
\end{tabular}

Sumber: Hasil Penelitian data diolah, 2019

Berdasarkan hasil uji pada tabel diatas menunjukkan bahwa semua variabel dalam penelitian ini dinyatakan reliabel karena nilai cronbach's alpha dari semua variabel memberikan nilai lebih besar dari 0,600 sebagai standar reliabel dan lebih besar dari nilai $r_{\text {tabel }} 0,2199$.

\subsection{Deskripsi Hasil Uji Hipotesis}


Published online in http://ejournal.uniflor.ac.id/index.php/analisis

Berikut peneliti uraikan hasil analisis berdasarkan uji simultan atau uji f pada pengujian hipotesis:

\section{Tabel 3. Hasil Uji Simultan F}

ANOVA ${ }^{\mathrm{a}}$

\begin{tabular}{|c|r|r|r|r|r|}
\hline Model & Sum of Squares & Df & Mean Squares & F & Sig \\
\hline Regression & 12,53 & 4 & 3.143 & 43.540 & $000^{\mathrm{b}}$ \\
\hline Residual & 5.414 & 75 & .072 & & \\
\hline Total & 17.988 & 79 & & & \\
\hline $\begin{array}{l}\text { a.Dependent Variable: Total Y (Pendapatan) } \\
\text { b.Predictors : (constant), Total X4(Lokasi), Total X3 (Jam kerja), Total X2 (Volume Penjualan), Total X1 (Modal } \\
\text { Awal) }\end{array}$ \\
\hline
\end{tabular}

Sumber: Hasil Penelitian data diolah, 2019

Pada uji simultan $\mathrm{F}$ diatas menunjukkan bahwa $\mathrm{f}_{\text {hitung }}$ sebesar 43.540 dan hasil signifikan sebesar $0,00 \%$, maka sesuai dengan rumus diatas $43.540>2,49$ dan uji signifikan $0,000<0,50$. Dapat disimpulkan bahwa variabel modal, jam kerja, volume penjualan dan lokasi memiliki pengaruh secara simultan dan signifikan secara bersamaan terhadap pendapatan pelaku UKM di Kecamatan Ende Utara.

Berikut peneliti uraikan hasil analisis berdasarkan uji parsial atau uji $\mathrm{T}$ pada pengujian hipotesis:

Tabel 4. Hasil Uji Parsial T

\begin{tabular}{|c|c|c|c|c|c|}
\hline \multirow[b]{2}{*}{ Model } & \multicolumn{2}{|c|}{$\begin{array}{c}\text { Unstandardized } \\
\text { Coefficients }\end{array}$} & \multirow{2}{*}{$\begin{array}{c}\begin{array}{c}\text { Standardized } \\
\text { Coefficients }\end{array} \\
\text { Beta }\end{array}$} & \multirow[b]{2}{*}{$\mathbf{T}$} & \multirow[b]{2}{*}{ Sig } \\
\hline & B & Std. Error & & & \\
\hline (Constant) & .162 & .303 & & .535 & .594 \\
\hline Modal Awal (X1) & .278 & .059 & .350 & 5.219 & .000 \\
\hline Volume Penjualan (X2) & .262 & .050 & .348 & 4.677 & .000 \\
\hline Jam Kerja (X3) & .191 & .052 & .255 & 3.667 & .000 \\
\hline Lokasi (X4) & .214 & .049 & .311 & 4.320 & .000 \\
\hline a.Dependent Variable T & & & & & \\
\hline
\end{tabular}

Sumber: Hasil Penelitian data diolah, 2019 
Berdasarkan hasil uji parsial statistik T pada tabel 4.5 diatas menunjukkan bahwa dari keempat faktor atau variabel terikat yang diteliti memiliki pengaruh yang berbeda beda antara lain:(1)Berdasarkan hasil Uji Parsial diatas maka ha terima dan ho ditolak Faktor Modal Awal X1 dengan nilai $\mathrm{T}$ sebesar 5.219>1.665dan nilai signifikansi sebesar $0,000<0,05$.(2)Berdasarkan hasil Uji Parsial diatas maka ha terima dan ho ditolak Faktor Volume Penjualan X2 dengan nilai T sebesar 4.677>1.665 dan nilai significansi sebesar 0,000<0,05.(3)Berdasarkan hasil uji parsial diatas maka ha ditolak dan ho diterima Faktor Jam Kerja X3 dengan nilai $\mathrm{T}$ sebesar 3.667>1.665dan nilai significansi sebesar 0,000<0,05 (4)Berdasarkan hasil Uji Parsial diatas maka ha terima dan ho ditolak Faktor Lokasi X4 dengan nilai $\mathrm{T}$ sebesar $4.320>1.665$ dan nilai significansi sebesar $0,000<0,05$. Berdasarkan hasil perhitungan pada uji parsial diatas menunjukan bahwa semua nilai $t$ hitung dari variabel modal, volume penjualan, jam kerja dan lokasi memiliki nilai t hitung lebih besar dari t tabel yaitu 1.665 dan semua nilai signifikansi dari semua variabel memiliki nilai lebih kecil dari criteria yaiitu 0,05. Maka dapat disimpulkan bahwa semua faktor dalam penelitian ini dinyatakan memiliki pengaruh secara significant terhadap Pendapatan Para Pelaku UKM Di Kecamatan.

\subsection{Uji Koefisien Determinasi}

Berikut adalah hasil uji koefisien determinasi yang telah diolah dengan menggunakan perhitungan spss:

Tabel 5. Uji Koefisien Determinasi

Model Summary ${ }^{b}$

\begin{tabular}{|c|c|c|c|c|}
\hline \multicolumn{1}{|c|}{ Model } & \multicolumn{1}{|c|}{ R Square } & Adjusted R Square & $\begin{array}{c}\text { Std. Error of the } \\
\text { Estimate }\end{array}$ \\
\hline 1 & .836 & .799 & .783 & 0.268 \\
\hline
\end{tabular}

Sumber: Hasil Penelitian data diolah, 2019

Berdasarkan hasil uji koefisien determinasi pada tabel 4.6 diatas menunjukkan bahwa Nilai Adjusted R Square 0.783 => 78,3 \% untuk Modal Awal (X1) Volume Penjualan (X2) Jam Kerja 
(X3) dan Lokasi (X4) mempunyai peran sebesar 78,3\% terhadap Pendapatan (Y) dan sisanya 21,7\% dipengaruhi oleh faktor di luar penelitian.

\subsection{Deskripsi Uji Koefisien Linear Berganda}

Berikut ini adalah hasil ui koefisien linear berganda yang telah diolah dengan menggunakan perhitungan SPSS:

Tabel 6. Hasil Uji Linear Berganda

Coeffients ${ }^{\mathrm{a}}$

\begin{tabular}{|c|c|c|c|}
\hline \multirow[b]{2}{*}{ Model } & \multicolumn{2}{|c|}{ Unstandardized Coffiecients } & \multirow{2}{*}{$\begin{array}{c}\begin{array}{c}\text { Standardized } \\
\text { Coefficients }\end{array} \\
\text { Beta }\end{array}$} \\
\hline & $\mathbf{B}$ & .Std.Error & \\
\hline (Constant) & .162 & .203 & \\
\hline Modal Awal (X1) & .278 & .059 & .350 \\
\hline Volume Penjualan (X2) & .262 & .050 & .348 \\
\hline Jam Kerja (X3) & .191 & .052 & .255 \\
\hline Lokasi (X4) & .214 & .049 & .311 \\
\hline at Verioble. & & & \\
\hline
\end{tabular}

Sumber: Hasil Penelitian data diolah, 2019

Berdasarkan hasil uji regresi linier berganda pada tabel diatas, maka dapat disusun persamaan linier berganda sebagai berikut:

$$
\begin{aligned}
Y & =a+b_{1} x_{1}+b_{2} x_{2}+b_{3} x_{3}+b 4 \times 4 Y \\
& =0,162+0.278 \times 1+.267 \times 2+.191 \times 3+.214 \times 4 .
\end{aligned}
$$

Dari persamaan regresi diatas maka peneliti dapat menyimpulkan dan menganalisis beberapa hal sebagai berikut:

1) Variabel Modal (X1) dengan nilai Unstandardized Coefficients sebesar 0,278 dan dinyatakan memiliki pengaruh yang paling dominan secara simultan terhadap pendapatan pelaku ukm 
dan indikator pendukung modal awal seperti besarnya modal awal dan modal pinjaman dan modal sendiri yang mempengaruhi besarnya pendapatan.

2) Variabel Volume Penjualan (X2) dengan nilai Unstandardized Coefficients 0,267 dan dinyatakan memiliki pengaruhsecara simultan terhadap pendapatan pelaku UKM di Kecamatan Ende Utara Kabupaten Ende.dan indikator pendukung volume penjualan adalah banyaknya jenis barang yang dijual di kios dan jenis barang yang dijual cepat laku sesuai dengan kebutuhan masyarakat.

3) Variabel Jam Kerja (X3) dengan nilai Unstandardized Coefficients 0,191dan dinyatakan memiliki pengaruh terhadap pendapatan para pelaku ukm dikecamatan ende utara kabupaten ende. hal ini terjadi karena didukung oleh beberapa indikator yaitu tingginya jam kerja dan pengaturan jam kerja yang baik.

4) Variabel Lokasi (X4) dengan nilai Unstandardized Coefficients 0,214 dinyatakan memeliki pengaruh yang dominan dari ketiga variabel lainya dengan indikator pendukung yaitu letak kios yang dekat dengan permukiman padat penduduk dan di depan jalan lalu lintas masyarakat.

Berikut adalah penyesuaian hasil uji hipotesis penelitian dan hasil analisis data sebagai berikut:

1) Variabel Modal, Volume Penjualan, Jam Kerja dan Lokasi memiliki pengaruh yang dominan terhadap pendapatan pelaku UKM kios di Kec. Ende Utara. Kab Ende.

2) Faktor yang memiliki pengaruh yang dominan sesuia dengan hipotesis pada penelitian ini adalah variabel X2 yaitu volume penjualan dengan total Unstandardized Coefficients sebesar 0,278 .

\section{KESIMPULAN}

Untuk meningkatkan pendapatan maka yang harus dilakukan adalah penambahan volume penjualan seperti barang-barang yang sering dibeli oleh masyarakat, selalu membuka setiap hari dari pagi hingga sore karena masyarakat memilki kebutuhan yang berbeda-beda terhadap barang kebutuhan rumah dan lainnya. Jika ingin membuka kios maka perlu dipertimbangkan modal yang besar agar pendapatan yang didapat akan besar dan dapat menguntungkan bagi pelaku UKM. Pengelolaan keuangan usaha juga perlu diperhatikan sehingga dapat melihat setiap keuntungan yang 
Published online in http://ejournal.uniflor.ac.id/index.php/analisis

didapat dan kerugian yang terjadi setiap bulan dan tahunnya, dengan demikian dapat dilakukan suatu perubahan jika dibutuhkan untuk menghindari kerugian keuangan.

\section{REFERENSI}

Amilia, S. (2019). Pengaruh Lokasi, Harga dan Fasilitas terhadap Keputusan Sewa Kamar Kost Mahasiswa Fakultas Ekonomi Universitas Samudra. Jurnal Manajemen dan Keuangan, 8(3), 267-280.

Beselly, X. D., Mawardi, M. K., \& Mawardi, M. K. (2017). Kebijakan Pengembangan Daya Saing Global Usaha Kecil Menengah (UKM) Di Kota Batu Menggunakan Sme Development Index. Jurnal Administrasi Bisnis, 47(1), 25-31.

Dewi, N. M. W. C., \& Arwiyah, M. Y. (2020). Pengaruh Jam Kerja Yang Panjang Dan Gaya Kepemimpinan Terhadap Kinerja Karyawan Pada PT Telkom Witel Bandung. Jurnal Ilmiah MEA (Manajemen, Ekonomi, \& Akuntansi), 4(3), 508-515.

Damariyah. (2015). Pengaruh Modal Kerja, Lama Usaha, Jam Kerja, Lokasi Usaha dan Tingkat Pendidikan Terhadap Pendapatan Pedagang. Skripsi S1 Program Studi Ekonomi Syari'ah STAIN Pekalongan.

Dewa M.A. Artaman (2015). Analisis Faktor-Faktor Yang Mempengaruhi Pendapatam Pedagang Pasar Seni Sukawati di Kabupaten Gianyar. Tesis S2 Program Pascasarjana Universitas Udayana Denpasar.

Ernawati, S., Asyikin, J., \& Sari, O. (2016). Penerapan Sistem Akuntansi Dasar pada Usaha Kecil Menengah di Kota Banjarmasin. WIGA: Jurnal Penelitian Ilmu Ekonomi, 6(2), 81-91.

Handoko, T Hani. 2000. Dasar-Dasar Manajemen Produksi dan Operasi, Edisi 1.Yogyakarta : BPFE

Maheswara, A., Setiawarna, N., \& Saskara, I. A. N. (2016). Analisis faktor-faktor yang mempengaruhi pendapatan UKM sektor perdagangan di Kota Denpasar. E-Jurnal Ekonomi dan Bisnis Universitas Udayana, 5(2016), 4271-4298.

Pradiani, T. (2017). Pengaruh sistem pemasaran digital marketing terhadap peningkatan volume penjualan hasil industri rumahan. Jurnal Ilmiah Bisnis Dan Ekonomi Asia, 11(2), 46-53.

Ritonga, M. (2018). Faktor Manajemen Biaya dan Manajemen Pemasaran Terhadap Pendapatan Melalui Intensitas Produksi pada UKM Industri Rumahan di Kota Binjai. JUMANT, 8(2), 6878.

Rosidi, A. M., \& Suparno, S. (2018). Pengaruh Modal dan Tenaga Kerja Terhadap Pendapatan Home Industri Sepatu di Kabupaten Sidoarjo (Study Kasus di Kecamatan Krian). JEB17: Jurnal Ekonomi dan Bisnis, 3(02).

Tutik Yuliati. (2012). Pengaruh Kedekatan Infrastruktur, Kedekatan Konsumen dan Biaya Lokasi Terhadap Pendapatan Pedagang di Areal Rute Jalan Lintas Selatan Kota Salatiga. Jurnal Among Makarti Vol.5 No.10.

Wicaksono Deddy .T. (2016). Analisis Faktor-Faktor Yang Mempengaruhi Pedagang Kaki Lima Penjual Bakso du Kota Semarang. 
JURNAL ILMIAH FAKULTAS EKONOMI UNIVERSITAS FLORES

VOL. 11 NO. 1 EDISI MARET TAHUN 2021

P. $68-80$

ISSN 1907-5189

e-ISSN 2722-6328

Published online in http://ejournal.uniflor.ac.id/index.php/analisis

Widya Utama dan I Gusti Bagus Adi. (2015). Faktor-Faktor Yang Mempengaruhi Pendapatan Pengusaha Perak di Desa Celuk Kec. Sukawati Kab. Gianyar. Tesis Universitas Udayana. Denpasar. 